\title{
High Efficiency Landfill Gas Fired Power Plant Process with ORC
}

\author{
Petri Kouvo \\ HSY Helsinki Region Environmental Services Authority, P.O. Box 100, FI-00066 HSY, Helsinki, Finland
}

\begin{abstract}
Helsinki Environmental Services Authority HSY Ämmässuo waste management centre consists of two landfill sites. The old land filling area was established in 1987 and closed in 2007. The landfilling at the new landfill section started in November 2007. Until spring 2014 the main treatment method for source separated MSW (municipal solid waste) collected from Helsinki Metropolitan area households was landfilling. Approximately 250,000 tonnes of MSW was landfilled annually. From April 2014 on all of the MWS has been utilized in heat and electricity production at new Waste to Energy plant owned and operated by energy company Vantaa Energy Ltd. The landscaping of the landfills is currently ongoing. The construction of the landfill gas collection system was started in 1994 and from 1996 on landfill gas from old landfill area was recovered and burned in torches to reduce the greenhouse gas effect caused by methane in landfill gas. In the end of year (2004) new landfill gas utilisation system was taken in use. Gas was used as a fuel in HOB (heat only boiler) to generate district heating for nearby community as well as commercial and industrial sites. The capacity of the system was $7,000 \mathrm{Nm}^{3} / \mathrm{h}$ that corresponded to app. $30 \mathrm{MW}$ of heat. Since district heat was mainly needed only during the cold season of the year only about half of the landfill gas produced by the landfill was able to utilize and rest of the gas was still flared leading to relatively low utilization rate of the gas. The construction work of the new $15 \mathrm{MW}+1.2 \mathrm{MW}$ electricity power plant started in spring 2009. The power plant consists of four gas engines and generators and organic rankine cycle process utilizing thermal oil for heat transfer from exhaust gas and steam turbine with hexamethyldisiloxane (silicone oil) as a medium agent. The ORC (Organic Rankine Cycle)-process was commissioned in August 2011 and the operational experiences have been very good. Based on current knowledge the HSY power plant is the biggest landfill gas fired power plant in Europe and probably even in the whole world. Also the combined engine and ORC-process is unique for landfill gas power plants. The third phase of the biogas utilization took place in summer 2015 when the anaerobic digestion biowaste treatment plant was introduced. At the moment the product gas from digestion plant is utilized at landfill gas power plant. In the future gas will be used as a fuel for new power plant process consisting two gas engines and ORC process. Commissioning of the new power plant will take place in October 2016. This paper presents detailed description of the landfill gas utilization system of HSY waste treatment centre and information on operational experiences of landfill gas fired power plant process.
\end{abstract}

Key words: Landfill gas, power production, ORC-process, waste management, biowaste, anaerobic digestion.

\section{Introduction}

HSY Helsinki Region Environmental Services Authority is a statutory, co-operative organisation operating in the municipalities of Helsinki the capitol of Finland, City of Espoo, City of Vantaa and City of Kauniainen which are located at Greater Helsinki area. HSY coordinates the waste management of four Helsinki Metropolitan area cities and owns and operates the largest waste treatment site in Finland. In

Corresponding author: Petri Kouvo, Ph.D., associate professor (Docent), research fields: waste management and waste to energy. addition to waste management HSY is responsible for water management, development planning (land use, population statistics etc.), and it also monitors the air quality in the metropolitan area [1].

The population of the Metropolitan area is around 1000000 that is approximately one fifth of the population of the whole Finland. Metropolitan area generates 4 million tonnes of wastes annually (2014). About 350,000 tons is generated in households and equal amount in public and private services while main part of the waste origins from construction activities (2.6 million tons in 2014). HSY organizes the household waste collection, transport and 
treatment of the whole Metropolitan area while the waste management of commercial activities area almost fully organized and operated by private companies. The recycling rate of household waste in Metropolitan area is more than $48 \%$ due to effective source separation of biowaste, paper, cardboard, metal and glass.

The waste management centre, Ämmassuo, consists of two large landfill areas and two composting plants and anaerobic digestion plant for biowaste. First landfill area was established in 1986 and was closed in the end of year 2007 due to EU landfill directive. In 2008 new landfill area was taken in use. Before spring 2014 Ämmässuo waste management centre received over 500,000 tonnes of various fractions of wastes annually. The amount of source separated household MSW (municipal solid waste) received and landfilled was 200,000-250,000 tonnes per year. The landfill area of 50 hectares that was in use until 2008 is equipped with landfill gas collection system. System consists of 220 gas wells, over 23 kilometres of gas pipelines, 3 regulating stations, 4 pumping stations, 3 flares, and drying and boosting unit for recovered landfill gas. Today landfills (old and new) are able to produce $8,000-9,000 \mathrm{Nm}^{3} / \mathrm{h}$ landfill gas with methane content of app. $50-52 \%$. Currently $6,500-7,000 \mathrm{Nm}^{3} / \mathrm{h}$ of gas is recovered. The gas production has been estimated to decrease slowly during the upcoming years due to decomposition of biodegradable waste. From 1996 on all of the recovered landfill gas has been treated by flaring. In November 2004 the boosting and drying unit and the pipeline connection to heat only power plant was taken in use. In boosting and drying unit the moisture content of the landfill gas was decreased from $15 \mathrm{~g} / \mathrm{Nm}^{3}$ to less than $5 \mathrm{~g} / \mathrm{Nm}^{3}$ and gas was pressurized to 1 bar level. Average of 4,500 (max. 5,200) $\mathrm{Nm}^{3} / \mathrm{h}$ of treated gas was transferred to the power plant via 11 kilometres long pipe line until spring 2010. Gas was utilised for district heat production in $40 \mathrm{MW}$ HOB (heat only boiler) that had been commissioned also in 2004. By using only landfill gas for heat production app. 25 MW power production was reached. In 2008 the boosting unit was taken in use and it was possible to increase the power production up to $37 \mathrm{MW}$. After the test period both the boosting and drying unit and the power generation unit worked without any major problems.

Due to insufficient demand of district heating and correspondingly relatively low utilization rate of landfill gas the planning of gas fired power plant was started. The plan was approved by the board of the HSY in summer 2008 and the construction work was started in May 2009. The commissioning of the plant was in April 2010. The gas fired power plant is equipped with four MWM gas engines with $15 \mathrm{MWe}$ power production. In 2011 the power plant process was equipped with ORC (Organic Rankine Cycle)-process to increase the power production for 1.3 MW. Due to quite unique combined process the power plant can reach high overall efficiency.

\section{Landfilling of Residual Waste}

The Ämmässuo landfill forms the largest disposal site in Nordic Countries. The total area of landfills is 115 hectares and the heaping area currently in use covers 50 hectares (old landfill). The construction works of the new landfill area started already in the beginning of 90's when there were no plans to build waste to energy plant. The original plan was to build 65 hectares new landfill area but after waste treatment strategy [2] of the metropolitan area was changed, the new landfill area built up was limited to approximate 20 hectares from which about 12 hectares is in active use today. The site was taken in use in 1987 and until the end of 2009 the volume of waste disposed was over 13 million tonnes. The current maximum height of the filling area is 65 meters. In 2013, 200,000 tonnes of residual household waste were deposited in Ämmässuo landfill [3].

Quarrying of the new land filling area of approximately 65 hectares was started already in 1992 . 
First parts of new area were taken use in the end of 2007. The cost estimation of building the new land filling area with the bottom layer construction meeting the EU-directive [4] demands, gas and waste water collection and treatment systems and with terminals is about 100 M€. Landfilling was the main waste treatment method for MSW until spring 2014. From that date on basically all of the MSW has been utilized at Waste to Energy plant in heat and electricity production. The aftercare of old and new landfill area will continue for at least 50 years consisting landfill gas collection, maintenance and reconstruction of landfill gas collection system as well as collection of leachate water from landfills. Even if the gas formation in landfills will still continue for many years the methane content of the gas will decrease in time being and the utilization of the gas may not be feasible any more after 10 years if gas is not boosted with product gas from for example AD-process or with natural gas.

\section{Landfill Gas Collection, Treatment and Utilization}

The anaerobic decomposition of organic waste in landfills produces landfill gas which is mainly a composition of carbon dioxide, methane and water vapour. Impurities such as hydrogen sulphide and halogen are present in small quantity. The degradation process of biowaste consists of four sequential steps. In aerobic stage the $\mathrm{O}_{2}$ content of the produced gas lowers down to zero and the $\mathrm{CO}_{2}$ content increases up to $30 \%$. During the second stage, the acid fermentation, $\mathrm{CO}_{2}$ content increases from $30 \%$ to $70-80 \%$ and at the same time the $\mathrm{N}_{2}$ content decreases closing the zero level. Around in two months the degradation process has reached the third stage, the unstable methane fermentation. In following two years during the methane fermentation the methane content of the gas increases up to $50 \%$ and the $\mathrm{CO}_{2}$ content lowers down to $40-45 \%$. After two years the methane fermentation has reached the stable stage and the methane formation continues stable for following 20-30 years. The factors influencing the degradation rate are among other things the quality of waste, humidity oxygen concentration, nutrients and temperature. One tonne of municipal solid waste can generate 100-200 normal cubic meter of gas [5]. Energy content of one cubic meter of landfill gas corresponds to $1 / 2$ cubic meter of natural gas or $1 / 2$ litre of fuel oil. The degradation process is presented in Fig. 1. Since methane is considered as a strong green house gas, around 20 times stronger than carbon dioxide,

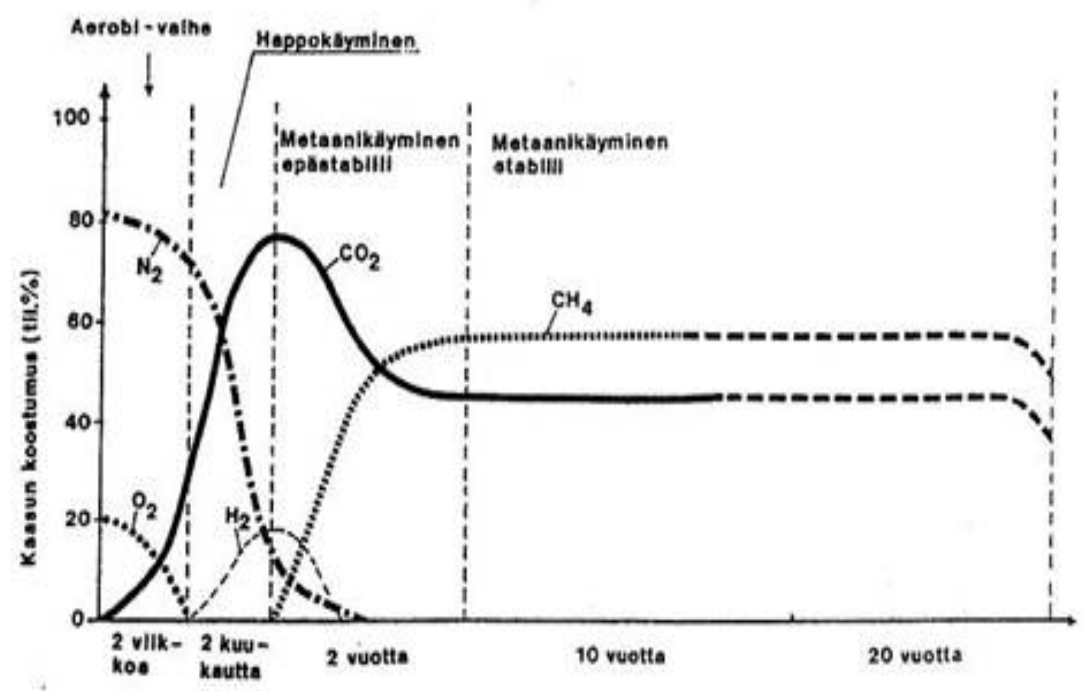

Fig. 1 Biowaste degradation process [5] (modified). 
Table 1 Composition of the Ämmäsuo disposal area landfill gas (in 2001 and 2003) [6].

\begin{tabular}{|c|c|c|c|c|}
\hline & & \multicolumn{2}{|c|}{ Analyse results } & \multirow{2}{*}{-Notes related to utilization } \\
\hline & & 2001 & 2003 & \\
\hline Methane & $\%$ & $53.6-58.5$ & $54.6-58.1$ & Fuel and green house gas \\
\hline Carbon dioxide & $\%$ & $37.1-37.9$ & $41.1-42.3$ & Possible utilization in industrial processes \\
\hline Nitrogen & $\%$ & $3.6-7.2$ & nd & Decreases the heating value of the gas \\
\hline Oxygen & $\%$ & 0 & $0-3.7$ & Explosive \\
\hline TVOC & $\mathrm{mg} / \mathrm{m}^{3}$ & $20-200$ & $301-706$ & Partly toxic \\
\hline Sulphur (tot.) & $\mathrm{mg} / \mathrm{m}^{3}$ & $107-247$ & 2,600 & Increases corrosion risk \\
\hline Halogenes (tot.) & $\mathrm{mg} / \mathrm{m}^{3}$ & $16.2-23.9$ & 0 & Corrosion and dioxin formation risk \\
\hline Si-compounds & $\mathrm{mg} / \mathrm{m}^{3}$ & $1.3-2.1$ & 7.6 & Damages in power engines (piston and turbine) \\
\hline Ammonia & $\mathrm{mg} / \mathrm{m}^{3}$ & $<2$ & nd & \\
\hline
\end{tabular}

and because of its easy utilization potentiality in energy production (heat and/or electricity), and because by effective collection of landfill gases the harmful odour problems can be avoided the recovery of landfill gas is ecologically and economically feasible.

The composition of the landfill gas recovered from Ämmässuo disposal area is presented in Table 1.

\section{Recovery and Treatment System}

The construction of the landfill gas collection system at Ämmässuo landfill started at the same time the filling of existing area was taken in use. Existing land filled waste volume produces approximately $9,000-10,000 \mathrm{Nm}^{3} / \mathrm{h}$ of gas. Due to effective collection network $70-80 \%$ of gas can be recovered. The gas production is estimated to decrease in following years.

The gas collection system consists of:

Old landfill:

- 220 gas wells situate horizontally and vertically;

- 4 (5) pumping stations;

- 7 regulating stations;

- 4 flares and

- drying and boosting station for the gas to be utilised.

New landfill:

- 65 vertical gas wells with bottom collection;

- 3 regulating stations with automatic suction pressure control;

- 1 pumping station.
The gas wells are located around 50 meters from each other building up a network that covers effectively the whole landfill area. Each well is covered with plastic hood and equipped with manual control valve. Gas is transported through the suction pipe to regulation station where the gas from separate wells is mixed to meet the quality demands. The network is presented in Fig. 2 and the illustration of the gas well is presented in Fig. 3.

Four gas pumping stations suck the gas from the wells through regulation stations and increase the gas pressure to 1 bar before the gas enters the drying and boosting station. To remove the excess humidity (from $15 \mathrm{~g} / \mathrm{Nm}^{3}$ to less than $5 \mathrm{~g} / \mathrm{Nm}^{3}$ ) the gas is cooled down to $+2{ }^{\circ} \mathrm{C}$ before boosting it. Boosting is done by two root compressors $\left(3,500 \mathrm{Nm}^{3} / \mathrm{h}\right)$. The caloric heating value of the gas is analysed and the volume of the gas is measured before gas enters the transfer pipe line. Fig. 4 shows the picture of the drying and boosting station.

\section{Landfill Gas Energy Production}

Until May 2010 boosted and dried LFG (landfill gas) was fed to the transfer pipe (DIN400) that leads to the power station located 11 kilometres away from the Ämmässuo waste management centre. The amount transferred was adjusted based on the local district heating capacity needed. Since the recovered gas amount was normally greater than amount needed for district heat production the excess gas was treated by burning it in torches at app. $1,200{ }^{\circ} \mathrm{C}$ temperature. The 


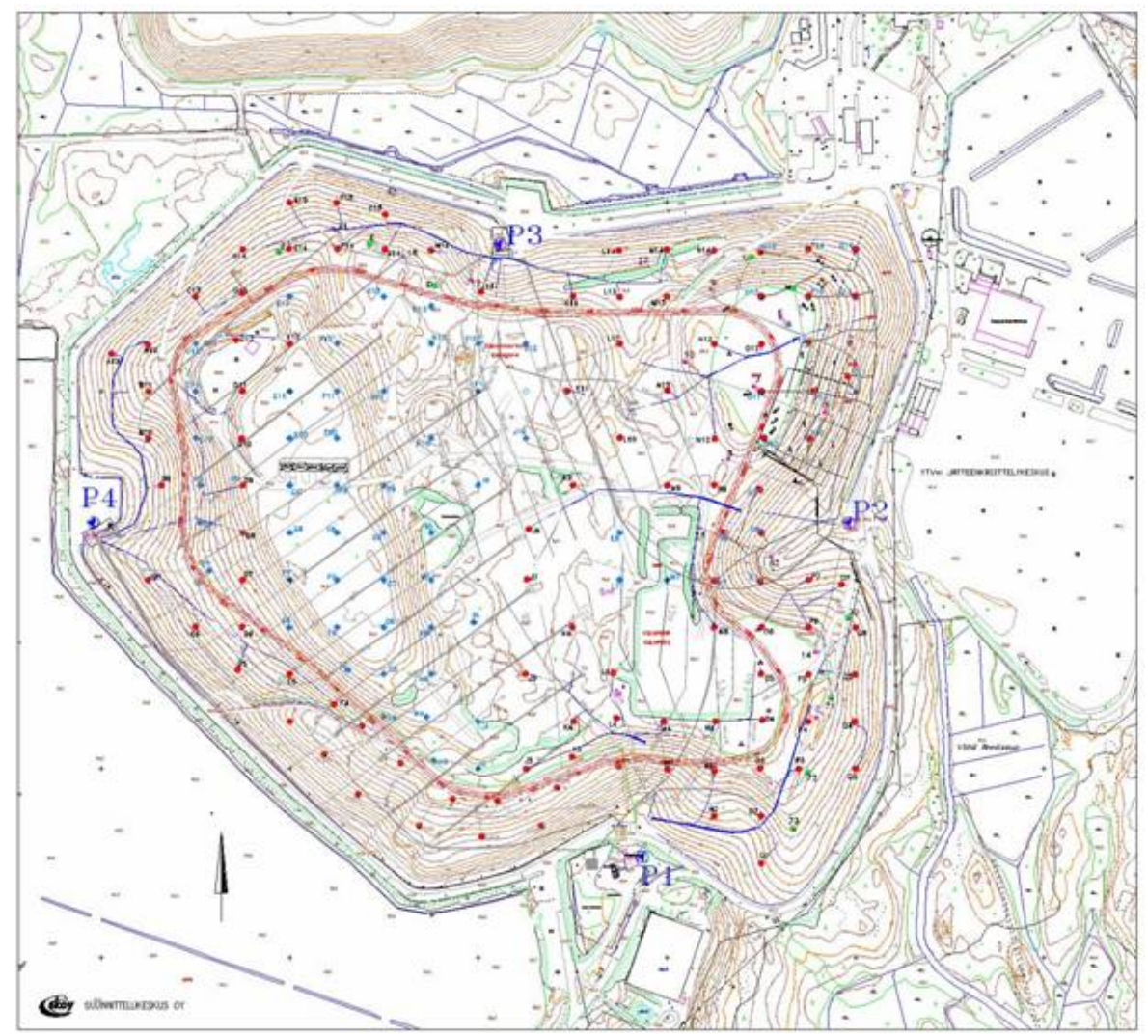

Fig. 2 The gas well network.

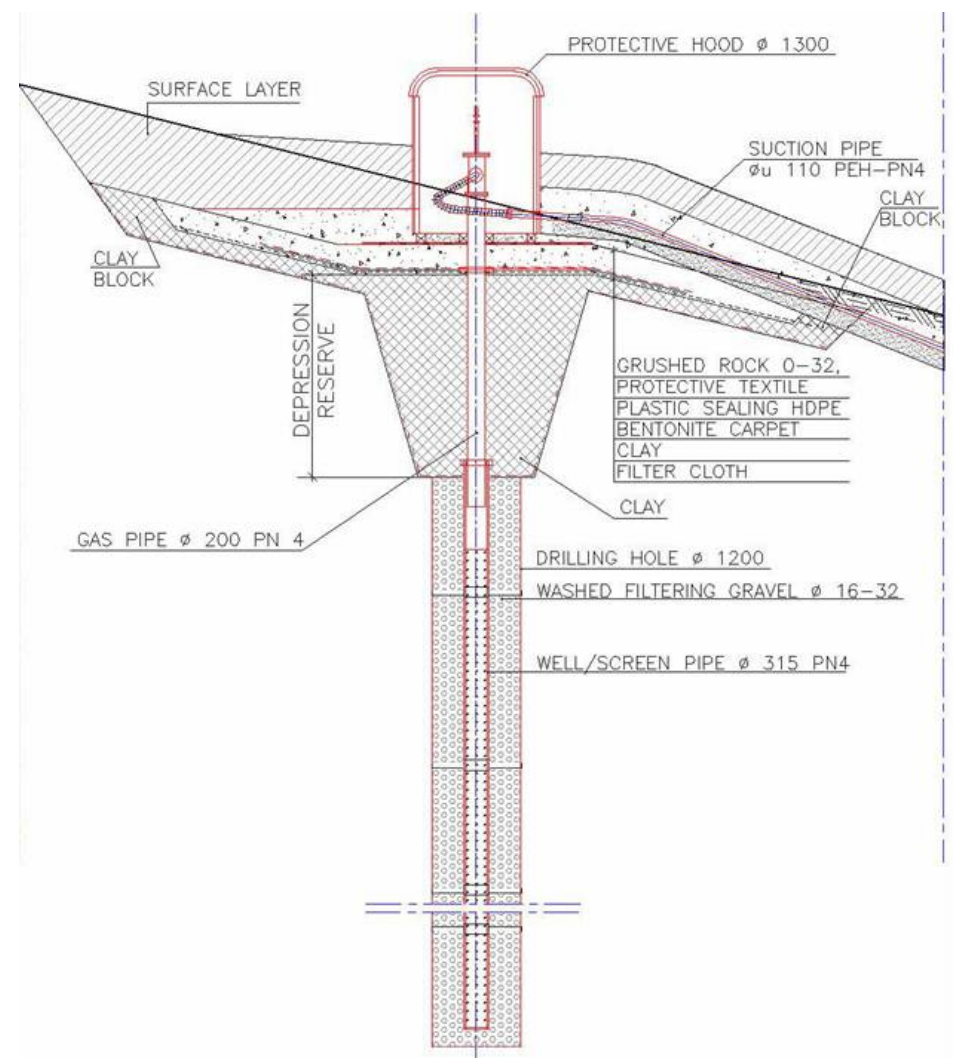

Fig. 3 Illustration of the gas well. 


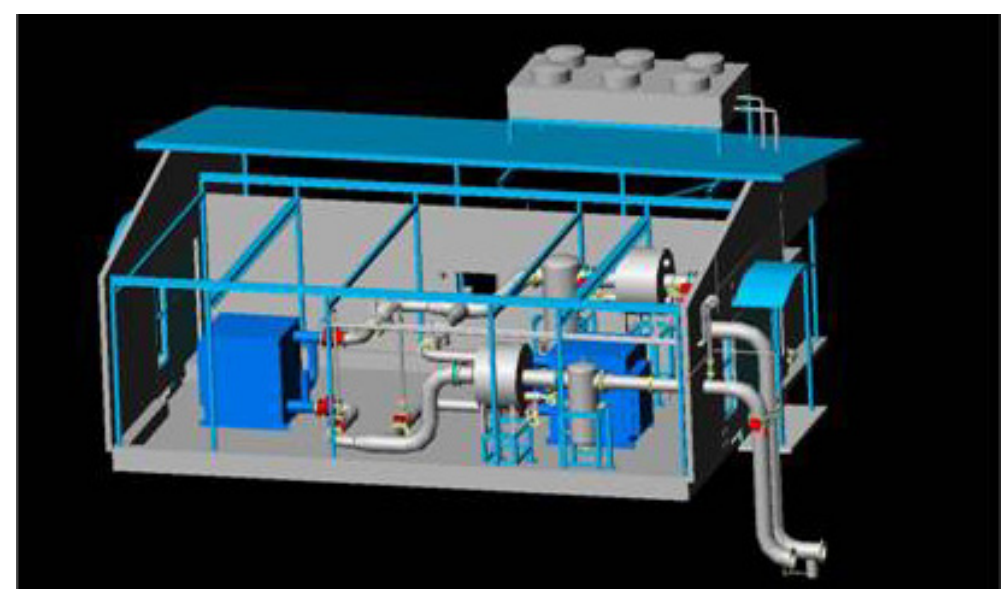

Fig. 4 The drying and boosting station.

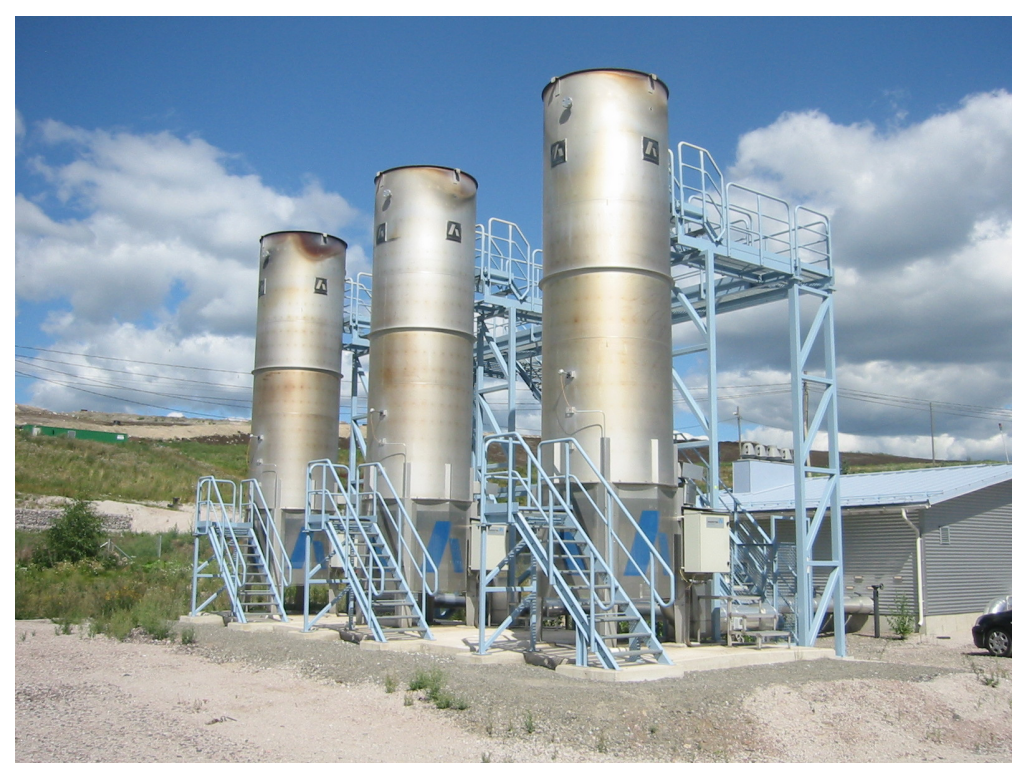

Fig. 5 The flaring station.

aim of flaring is to convert methane in LFG into less harm full green house gas $\mathrm{CO}_{2}$. The picture of the flaring station is presented in Fig. 5 .

The district heating power station is owned and operated by local energy company Fortum Ltd. The station consists of three HOB. Two of them are older heavy oil fired boilers that are used mainly for peaking periods. Third boiler can be fired with LFG or heavy oil. After robust filtering the gas was entered the gas burner. The maximum thermal output of the boiler is $40 \mathrm{MW}$ but currently average of $25 \mathrm{MW}$ was reached with LFG due to lower heating value of the gas compared to heavy oil and the gas transfer capacity limitations. The consumption of the gas on full load was app. 4,500 (max 5,200) $\mathrm{Nm}^{3} / \mathrm{h}$. Gas burnt in over $1,000{ }^{\circ} \mathrm{C}$ temperature and the water in district heating network is heated up from $44-55{ }^{\circ} \mathrm{C}$ to 77-120 ${ }^{\circ} \mathrm{C}$. Due to low emission levels of LFG combustion the flue gas treatment was not used but the flue gases were led into stack directly after the short duct.

Landfill gas utilization system (boosting and drying station, the transfer pipeline and the boiler) was taken in use in October 2004. After few months of test run period the system has had no functional problems.

\section{New Landfill Gas Fired Power Plant}

By being among the biggest waste treatment facilities 
in northern Europe HSY has thoroughly evaluated options for the utilization of Ämmässuo landfill gas. With several feasibility studies the following utilisation options were evaluated:

- Vehicle fuel production;

- Feed into natural gas network;

- District heat production;

- Onsite CHP production.

Being located outskirts of any energy networks the onsite CHP production was favoured. CHP option was also favoured due to the Government Programme in Finland (2007) where it was stated that electricity production from biogas will be subvented by the State. During year 2007 HSY received an environmental permit for CHP production either with technology based on turbines or engines. Engine technology was favoured due to more robust structure and better partial load efficiencies.

During winter 2008 HSY called for tenders for a power plant process supply equalling $15 \mathrm{MW}$ electricity production. Finally a solution based on four MWM TCG 2032 engines won the tender evaluation. The selected engine type is the biggest ever gas engine to be fired with landfill gas. The technical details of TCG 2032 engines are presented in Table 2.

Landfill gas contains impurities which have to be removed from the fuel gas prior delivery to the gas engines. In a gas pre-treatment unit silicon compounds (Siloxanes) and hydrogen sulphide $\left(\mathrm{H}_{2} \mathrm{~S}\right)$ are removed to reduce environmental emissions and significantly reduce engine maintenance costs. Siloxanes cause physical wear for the engines and tend to accumulate in pistons and valves of the engines. Hydrogen sulphide and other sulphur compounds lead to chemical corrosion of the engine.

Siloxanes are absorbed into special filter media that can be automatically regenerated by hot air injection to achieve extended life time for the filter medium. Compared to traditional activated carbon the regenerative media has a life time up to five years before it has to be replaced. The working principle of the gas pre-treatment system is presented in Fig. 6.

Table 2 Technical details of MWM TCG 2032 gas engine [7].

\begin{tabular}{lll}
\hline Parameter & Unit & Value \\
\hline Length & $\mathrm{mm}$ & 8,900 \\
Width & $\mathrm{mm}$ & 2,750 \\
Height & $\mathrm{mm}$ & 3,800 \\
Dry weight & $\mathrm{kg}$ & 47,600 \\
Electricity production & $\mathrm{kW}$ & 3,765 \\
Electrical efficiency & $\%$ & 42.0 \\
Thermal efficiency & $\%$ & 44.1 \\
Total efficiency & $\%$ & 86.1 \\
\hline
\end{tabular}

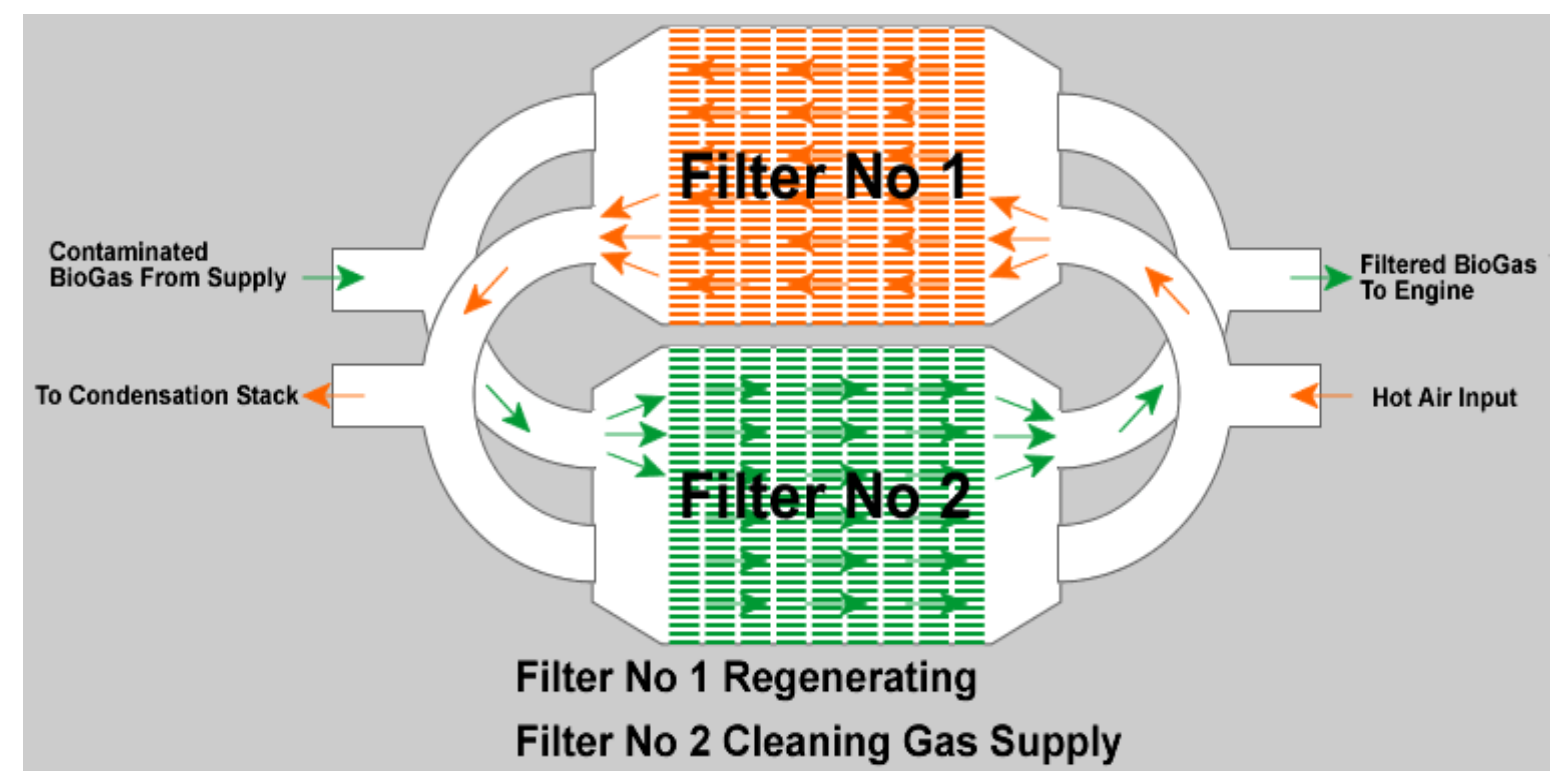

Fig. 6 Working principle of the gas pre-treatment system (Pp Tek Ltd., 2010). 
Due to strict limits and requirements set to the power plant by the environmental authorities HSY started to evaluate possibilities for waste heat utilization originating from the electricity production. More than $12 \mathrm{MW}$ of heat can be recovered as a result of the electricity production. This heat can be recovered from the engine cooling water, engine oil and from the exhaust gases. By the end of 2010 all heat recovered from the engine cooling and oil $(\sim 4$ MW) can be utilized during heating season in the local district heating system to supply heat for offices and process facilities within the landfill.

ORC-process can utilize $90 \%$ from the exhaust gases from the power plant in additional electricity production. In ORC process heat exchangers are used to transfer up to $7 \mathrm{MW}$ of heat into thermo-oil system. Thermo-oil is heated up to $300{ }^{\circ} \mathrm{C}$ temperature. This heated thermo-oil is then used to evaporate working fluid (hexamethyldisiloxane) with low evaporation temperature. Vapour pressure caused by this evaporation is then used in a turbine for electricity production.

ORC units are normally operating with about $20 \%$ efficiencies. With a given thermal load of $7 \mathrm{MW}$ to the ORC process an additional electricity production of 1.3 MW can be expected. After implementing the ORC process HSY can increase the electrical efficiency of the power plant from $42 \%$ up to $46 \%$. A schematic presentation of ORC process is presented in Fig. 7.

Power plant is connected into three different electrical networks. It supplies electricity directly to Ämmässuo $20 \mathrm{kV}$ electricity network to be used in waste treatment unit processes. But since the electricity production largely exceeds the areal consumption the power plant is also connected to 20 $\mathrm{kV}$ local grid and finally to $110 \mathrm{kV}$ national grid. Due to these state of art investment decisions the Ministry of Employment and the Economy in Finland has awarded HSY with 3.4 million euro as an investment support.

\section{Conclusions}

HSY, Helsinki Region Environmental Services Authority coordinates the waste management of four Helsinki Metropolitan area cities and owns and operates the largest waste treatment site in Finland. The waste management centre, Ämmassuo, consists of two large landfill sites and composting plant for biowaste. The landfill area of $50+12$ hectares that

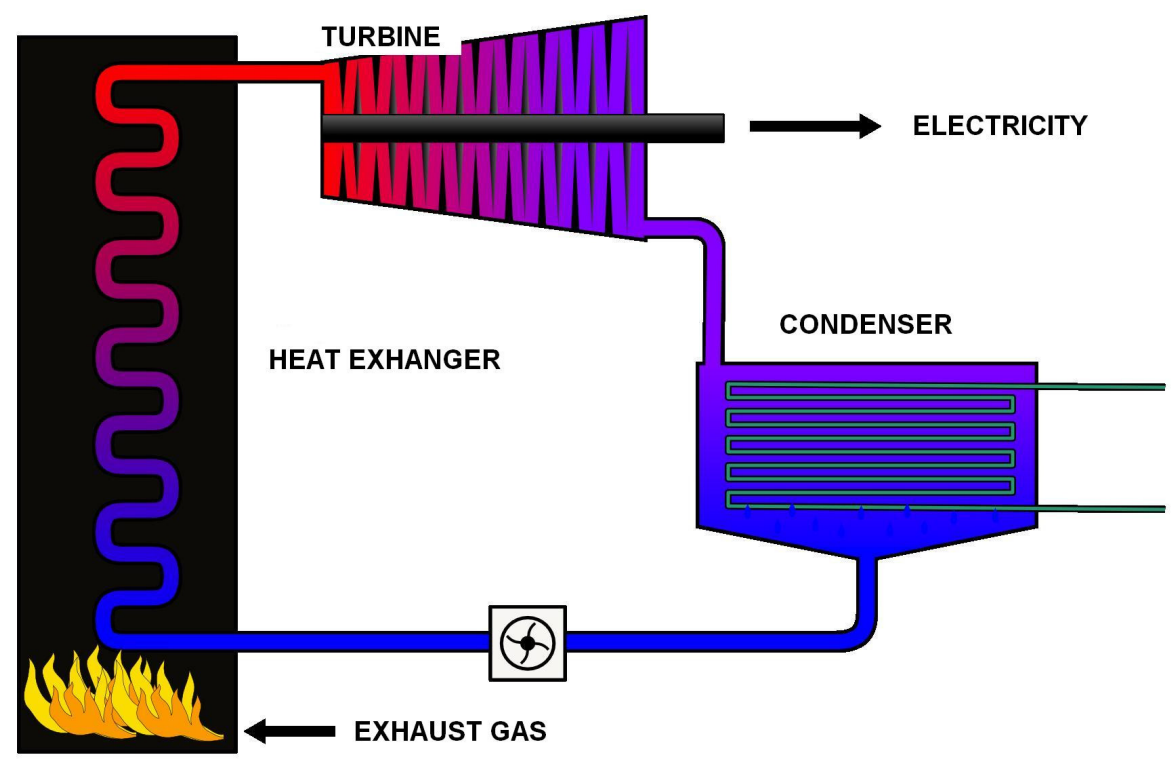

Fig. 7 Schematic presentation of ORC process. 


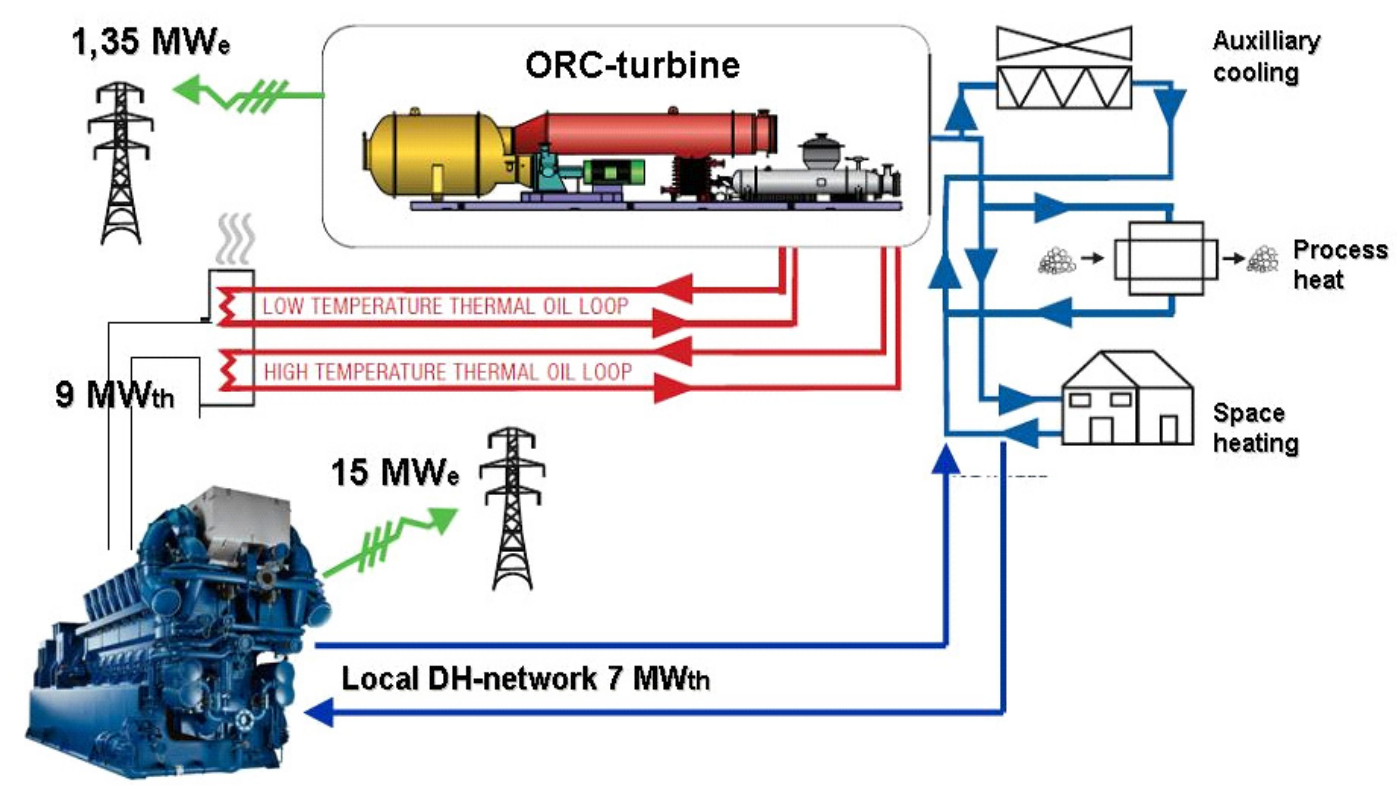

\section{Energy utilisation concept in Ämmässuo LFG power plant}

Fig. 8 Energy utilisation concept of Ämmässuo LFG power plant.

was used until spring 2014 is equipped with enhanced landfill gas collection network. The network consists of 220 gas well, 23 kilometres of gas pipes, 3 regulating stations, 4 pumping stations, 3 flares, and drying and boosting unit. Existing landfill is able to produce $9,000-10,000 \mathrm{Nm}^{3} / \mathrm{h}$ landfill gas with methane content of app. 50-52\%. Currently $6,500-7,000 \mathrm{Nm}^{3} / \mathrm{h}$ of gas is collected. From 1998 on all the collected has been treated by flaring. In November 2004 the boosting and drying unit and the pipeline was taken in use. In boosting and drying unit the moisture content of the landfill gas was decreased from $15 \mathrm{~g} / \mathrm{Nm}^{3}$ to less than $5 \mathrm{~g} / \mathrm{Nm}^{3}$ and gas was pressurised to 1 bar. Average of $4,500 \mathrm{Nm}^{3} / \mathrm{h}$ of treated gas was transferred to the power plant via 11 kilometres long pipe line. Gas was utilised for district heat production in $40 \mathrm{MW}$ heat only boiler. With landfill gas only app. $25 \mathrm{MW}$ power production was reached. With additional boosting of the landfill gas the power output was increased up to $37 \mathrm{MW}$. After the test period both the boosting and drying unit and the power generation unit worked without any major problems. In summer 2009 the decision to build a gas fired power plant was made by the HSY board. After completion the power plant forms the biggest landfill gas power plant in Northern Europe and a major producer renewable energy in the Helsinki Metropolitan area. It will make HSY totally independent when considering electricity and heat consumption. Excess electricity will be sold to the national grid. The combine engine ORC-process has shown to increase the electricity production more than 1.3 MW which equals with electricity consumption of the waste treatment centre. The ORC process has had no major operational problems but worked well with routine maintenance efforts. Due to relatively high content of impurities in landfill gas new gas cleaning facility has been connected to the system to avoid formation of impurities, mainly siloxanes, in the valves and piston heads of the engines. State of art technology leads also to lower emission levels to the atmosphere and higher total efficiencies. 


\section{References}

[1] Yearbook of Helsinki Region Environmental Services Authority HSY, 2014. HSY, Pasila, Finland 2014.

[2] Waste Management Strategy of YTV, 2004. YTV, Pasila, Finland 2004.

[3] The Annual Report of Ämmässuo Waste Management Centre, 2013. HSY, Pasila, Finland, March 2014.

[4] "Commission of the European Communities, European Parlieament and Council, Directive 1999/31/EC."
Landfill of Waste. The Official Journal of the European Communities: 182.

[5] Tchobanoglous, G., Theisen, H., and Vigil, S. A. 1993. Integrated Solid Waste Management, Engineering Principles and Management Issues. Civil Engineering Series, McGraw-Hill International Editions.

[6] YTV Waste Management Department. 2003. Ämmässuo Landfill Gas Composition. Internal research report, Helsinki, Finland. (in Finnish)

[7] MWM GmbH. "Technical Document for Gas Engine TCG 2032." 